\title{
Mössbauer Studies of the Membrane-Associated Methane Monooxygenase from Methylococcus capsulatus Bath: Evidence for a Diiron Center
}

\author{
Marlène Martinho†, Dong W. Choi ${ }^{\dagger}$, Alan A. DiSpirito I, William E. Antholine ${ }^{\#}$, Jeremy D. \\ Semrau§, and Eckard Münck ${ }^{\dagger},{ }^{*}$ \\ $\dagger$ Department of Chemistry, Carnegie Mellon University, Pittsburgh, PA 15213 \\ II Department of Biochemistry, Biophysics and Molecular Biology, Iowa State University, Ames, IA \\ 50011-3211 \\ \# Department of Biophysics, Medical College of Wisconsin, Milwaukee, WI 53226 \\ $\S$ Department of Civil and Environmental Engineering, University of Michigan, Ann Arbor, MI 58109-2125
}

Methane monooxygenase (MMO) catalyzes the energy dependent oxidation of methane to methanol in methanotrophic bacteria. ${ }^{1,2}$ In these organisms two different methane monooxygenases have been identified, namely a membrane-associated or particulate MMO (pMMO) and a cytoplasmic or soluble MMO (sMMO). In methanotrophs that express both forms of the enzyme, the copper concentration during growth dictates which MMO is expressed. $^{2-5}$ In cells cultured under a low copper/biomass ratio, the sMMO is predominately expressed, whereas cells cultured at higher copper/biomass ratios exclusively express the pMMO (sMMO is not transcribed). ${ }^{6-8}$ The sMMO is a well characterized three-component enzyme consisting of a hydroxylase, a reductase and a regulatory protein. ${ }^{9-12}$ Spectroscopic and X-ray crystallographic studies have established that the hydroxylase contains an oxygen bridged diiron cluster. ${ }^{13-16}$ Here we provide evidence that pMMO contains a diiron cluster as well.

Owing to the low specific activity and instability of most pMMO preparations, $6,17-20$ comparatively little is known about the molecular properties of this enzyme. As isolated, pMMO is composed of three polypeptides with molecular masses of 45,000, 26,000, and 23,000 Da with a subunit structure of $(\alpha \beta \gamma)_{3}{ }^{6}{ }^{6}, 17,18,20-22$ Most researchers agree that each $\alpha \beta \gamma$ contains $2-3 \mathrm{Cu}$ atoms $2,6,17-20,23$ although one group has suggested that $15 \mathrm{Cu}$ atoms are arranged into catalytic and electron transfer trinuclear copper clusters. $22,24,25$ The 2.8 $\AA$ resolution crystal structure of pMMO revealed that each $\alpha \beta \gamma$ contained a dicopper site, a mononuclear copper site, and a third site occupied by zinc. ${ }^{21,} 23$ However, the preparation used for growing the crystal was inactive and did not contain zinc (which was added to the crystallization buffer). ${ }^{21,23}$

The involvement of non-heme iron in methane oxidation by the pMMO has been proposed by some laboratories $6,17,26-29$ and disputed by others. ${ }^{22,24,30}$ In our laboratory at Iowa State University we have observed that preparations of pMMO showing highest specific activity contain 1-2 iron atoms. ${ }^{6}$ We therefore decided to employ Mössbauer spectroscopy to characterize the iron components. This technique is particularly well suited to explore iron environments that are EPR-silent and optically uninformative in the visible region, as is the 
spin-coupled diiron(III) center of the hydroxylation component of sMMO. It seemed reasonable to us to search for a similar diiron cluster because this is the only type of center known to oxidize methane to methanol at room temperature.

The 4.2 K Mössbauer spectrum of the antiferromagnetically coupled diiron(III) centers of sMMO consists of a doublet with quadrupole splitting $\Delta \mathrm{E}_{\mathrm{Q}}=1.12 \mathrm{~mm} / \mathrm{s}$ for the $M$. capsulatus Bath enzyme 15,31 and $\Delta \mathrm{E}_{\mathrm{Q}}=1.02 \mathrm{~mm} / \mathrm{s}$ for that of $M$. trichosporium $\mathrm{OB}_{3} \mathrm{~b}^{13}$, 16 ; both enzymes have an isomer shift $\delta=0.50 \mathrm{~mm} / \mathrm{s}$ at $4.2 \mathrm{~K}$ (The clusters of the two enzymes yield broad absorption lines and equivalent fits have been obtained by assuming different $\Delta \mathrm{E}_{\mathrm{Q}}$ values for the two iron sites; see ref $13,15,16,31$ ).

Table 1 lists analytical and activity data of our purified pMMO sample and of whole cells grown at high copper $(80 \mu \mathrm{M})$ and iron $(40 \mu \mathrm{M})$; the entries are discussed in the Supporting Information. Figure 1 shows $4.2 \mathrm{~K}$ Mössbauer spectra of purified pMMO. The central portion of the $45 \mathrm{mT}$ spectrum (Figure 1A) exhibits two overlapping doublets with $\Delta \mathrm{E}_{\mathrm{Q}}(1)=1.05 \mathrm{~mm} /$ $\mathrm{s}, \delta(1)=0.50 \mathrm{~mm} / \mathrm{s}(\approx 20 \%$ of total Fe $)$ and $\Delta \mathrm{E}_{\mathrm{Q}}(2)=2.65 \mathrm{~mm} / \mathrm{s}, \delta(1)=1.25 \mathrm{~mm} / \mathrm{s}(\approx 18 \%$ of total $\mathrm{Fe}$ ); the $\delta$ value of doublet 2 is characteristic of a high-spin $\mathrm{Fe}^{2+}$ with octahedral N/O coordination. The majority of the iron in the spectrum of Figure 1A, perhaps up to $60 \%$ of total $\mathrm{Fe}$, belongs to a heterogeneous population of $\mathrm{Fe}^{3+}$ species exhibiting magnetic hyperfine structure with splittings up to $17 \mathrm{~mm} / \mathrm{s}$ Doppler velocity. This $\mathrm{Fe}^{3+}$ fraction is EPR silent at $\mathrm{X}$-band (Figure $\mathrm{S} 3$ ), and its $\Delta \mathrm{E}_{\mathrm{Q}}$ and $\delta$ values $(0.63 \mathrm{~mm} / \mathrm{s}$ and $0.51 \mathrm{~mm} / \mathrm{s}$ at $120 \mathrm{~K})$ are the same as those reported for mineralized nanoparticles (attributed to ferric phosphate) in mitochondria of yeast frataxin homolog ( $\delta$ yfh 1 ) mutants. ${ }^{32}$ The $\Delta \mathrm{E}_{\mathrm{Q}}$ and $\delta$ values of doublet 1 match those reported for the diiron(III) centers of sMMO. The solid line in Figure 1A is a spectral simulation representing two doublets 1 and 2, drawn such that their sum represents $38 \%$ of the total iron; the features of doublet 1 are indicated by the offset dashed line.

The spectrum of Figure 1B was recorded in an applied magnetic field of $8.0 \mathrm{~T}$. Most interestingly, the $8.0 \mathrm{~T}$ spectrum shows that the iron of doublet 1 belongs to a diamagnetic $(\mathrm{S}=0)$ center, as demonstrated by the spectral simulation outlined by the vertically displaced solid line. The values of $\Delta \mathrm{E}_{\mathrm{Q}}(1)$ and $\delta(1)$, together with the observed diamagnetism of this spectral component, strongly suggest that doublet 1 represents an antiferromagnetically coupled diiron(III) center similar to that found in sMMO.

Mössbauer spectroscopy is a very useful technique for the study of iron-containing proteins in whole cells, provided the concentration of the targeted proteins can be increased by overexpression $^{33}$ or by employing special growth conditions. Since $M$. capsulatus Bath produces large amounts of pMMO $(\approx 20 \%$ of whole cell protein $)$ when grown at high copper and iron concentrations, we were curious whether doublet 1 would be observed in whole cells. We have found that maximal pMMO activity in cell free fractions requires the addition of approximately $40 \mu \mathrm{M}$ iron in conjunction with $80 \mu \mathrm{M}$ copper in the culture media. We have recorded Mössbauer spectra of whole M. capsulatus Bath cells grown on media high in copper and iron between $1.5 \mathrm{~K}$ and $120 \mathrm{~K}$ in applied fields up to $8.0 \mathrm{~T}$. Figures $2 \mathrm{~B}$ and $2 \mathrm{D}$ show two representative $4.2 \mathrm{~K}$ spectra. The signal strength of the Mössbauer spectrum of Figure 2B indicates that the cells contain roughly $5 \mathrm{mM}{ }^{57} \mathrm{Fe}$, in good agreement with the chemical analysis $(5.2 \mathrm{mM})$. Ca. $40 \%$ of the iron belongs to a magnetic component of high-spin $\mathrm{Fe}^{3+}$ outlined by the solid line in (B); it yields a doublet with $\Delta \mathrm{E}_{\mathrm{Q}} \delta \approx 0.6 \mathrm{~mm} / \mathrm{s}$ and $\delta=0.45 \mathrm{~mm} /$ $\mathrm{s}$ at $120 \mathrm{~K}$ (not shown). This component exhibits spectra typical of superparamagnetic nanoparticles, 32,34 probably composed of mineralized excess iron accumulated during aerobic growth at high Fe concentrations. Simulation of the $45 \mathrm{mT}$ spectrum of the superparamagnetic component of Figure 2B is quite straightforward (but not unique); however, fitting the outer four lines fixes position and intensities of the two innermost lines of the sixline pattern. Subtraction of the simulated superparamagnetic component from the raw data 
yields a spectrum (Figure 2 C) which exhibits doublet $1(\approx 20 \%$, solid line) with exactly the same parameters as observed in the purified enzyme. Also observed is a high-spin $\mathrm{Fe}^{2+}$ species with $\Delta \mathrm{E}_{\mathrm{Q}} \approx 3.00 \mathrm{~mm} / \mathrm{s}$ and $\delta \approx 1.25 \mathrm{~mm} / \mathrm{s}$. The solid line in the $8.0 \mathrm{~T}$ spectrum of Figure 2D is a spectral simulation showing that the iron of doublet 1 , as in the purified protein, belongs to a diamagnetic center. The broad features, stretching from ca. $-9 \mathrm{~mm} / \mathrm{s}$ to $+9 \mathrm{~mm} / \mathrm{s}$ Doppler velocity, belong to the superparamagnetic components ${ }^{35}$ and the $\mathrm{Fe}^{2+}$ species. Finally, Figure $2 \mathrm{~A}$ shows a $4.2 \mathrm{~K}$ Mössbauer spectrum of cells grown at low $\mathrm{Cu}$ and ${ }^{57} \mathrm{Fe}$ concentrations (each $5 \mu \mathrm{M} ; \mathrm{pMMO}<5 \%$ of total cell protein) where pMMO expression is reduced four fold. ${ }^{6}$ Compared to the sample of Figure 2B the signal amplitudes have declined by at least a factor 15 , showing that the iron observed in the spectra of Figure $2 \mathrm{~B}$ and $\mathrm{D}$ accumulates when the cells are growing at high $\mathrm{Cu}$ and $\mathrm{Fe}$ concentrations.

The purified pMMO sample (1.06 $\mathrm{mM} \alpha \beta \gamma)$ had an iron concentration of $1.2 \mathrm{mM}$. If we associate the iron of doublet 1 with a diiron(III) cluster, we obtain a site occupancy of ca. 11\%, assuming that pMMO can accommodate one diiron center $/ \alpha \beta \gamma$. The cells of Figure $2 \mathrm{~B}$ had 5.2 $\mathrm{mM}$ iron, yielding $0.2 \times 5.2 / 2=0.52 \mathrm{mM}$ diiron centers. In previous experiments we estimated that ca. $20 \%$ of the protein in cells cultured in media containing on $80 \mu \mathrm{M} \mathrm{Cu}$ and $40 \mu \mathrm{M} \mathrm{Fe}$ belongs to pMMO. ${ }^{6}$ Using this estimate, the sample of Figure $2 \mathrm{~B}$ has $0.56 \mathrm{mM}$ pMMO, suggesting that pMMO in thus cultured cells has $\eta 0.93$ diiron(III) center $/ \alpha \beta \gamma$. The above estimates agree quite well with the observation that we recover ca. $10 \%$ of activity after purification of the protein.

We have assigned doublet 1 to a diiron(III) center. The Mössbauer properties of doublet 1 are also compatible with those observed for some low-spin ferrous hemes, such as cytochromes $c$ and $b$, and $[4 \mathrm{Fe}-4 \mathrm{~S}]^{2+}$ clusters. However, the UV/visible spectrum of the Mössbauer sample (Figure S2) indicates less than 0.005 hemes $/ \alpha \beta \gamma$, and the cellular concentration of heme in cells cultured in $5 \mu \mathrm{M} \mathrm{Cu}$ and $5 \mu \mathrm{M} \mathrm{Fe}$ is essentially identical to cells cultured in $80 \mu \mathrm{M} \mathrm{Cu}$ and 40 $\mu \mathrm{M} \mathrm{Fe} .{ }^{20}[4 \mathrm{Fe}-4 \mathrm{~S}]^{2+}$ clusters can be excluded by observing that pMMO has only one cysteine residue, Cys 92 on the $\alpha$ subunit, ${ }^{21,36}$ and that the presence of sulfide has not been reported by any laboratory.

The $\mathrm{Fe}^{2+}$ component(s) observed in whole cells have a larger $\Delta \mathrm{E}_{\mathrm{Q}}$ than the $\mathrm{Fe}^{2+}$ species observed in Figure 1A, and thus represent a different type of $\mathrm{Fe}^{2+}$, plausibly iron bound to transporters and storage components. Perhaps as much as $60 \%$ of the iron observed in the purified pMMO sample of Figure 1 belongs to high-spin Fe. ${ }^{3+}$ The EPR spectra of Figure S3 are almost devoid of iron associated signals; the resonances at $\mathrm{g} \approx 6$ and 4.3 account each for at most $10 \mu \mathrm{M} \mathrm{Fe}^{3+}$, i. e. only $1 \%$ of the iron. We suspect that the EPR-silent $\mathrm{Fe}^{3+}$ represents remnants of the mineralized fraction observed in whole cells that copurify with the enzyme.

We have observed similar EPR-silent $\mathrm{Fe}^{3+}$ fractions in other proteins studied in our laboratory; invariably, these fractions disappeared as purification procedures improved. The reader may wonder whether doublet 1 could represent a dimer fraction of a mineralized $\mathrm{Fe}^{3+}$. We have recently studied Mössbauer spectra of yahl-depleted mitochondria from aerobically grown $S$. cerevisiae. For this mutant (which lacks iron-sulfur proteins) all detectable iron (2-3 mM) could be assigned to $\mathrm{Fe}^{3+}$ nanoparticles, with no evidence for a diamagnetic dimer fraction (unpublished results).

Given the similarities of the Mössbauer parameters of doublet 1 with those observed in sMMO, it is reasonable to propose that $\mathrm{pMMO}$ has an active site consisting of a diiron cluster, and that this cluster is bound in the site occupied by $\mathrm{Zn}$ from the crystallization buffer, a possibility indicated by Lieberman and Rosenzweig. ${ }^{21}$ Interestingly, this site has two conserved His and two conserved carboxylate (His 160 and 173, Asp 156 and Glu 195). Moreover, the site has four additional nearby residues with carboxylates functions, Glu 69, Glu 176, Asp 166 and Asp 168, which are conserved in all known pMMO sequences. Thus, as shown in Figure 3A, 
the "Zn site" of pMMO has the requisite ligands to accommodate a sMMO type diiron center, and has suggestive similarities with the diiron site of sMMO, shown in Figure 3B. Placing the active site of pMMO into the "Zn site" is supported by the observation that exposure of the cells or purified pMMO to ${ }^{14} \mathrm{C}$-acetylene, a suicide substrate for $\mathrm{pMMO}$, yields labeled $\beta$ subunits (the copper sites of pMMO are located on $\alpha$ ). ${ }^{20,37-39}$ With a target spectral signature, the loss of iron during purification of pMMO can now be studied by recording Mössbauer spectra through the various steps of the purification procedure.

\section{Supplementary Material}

Refer to Web version on PubMed Central for supplementary material.

\section{Acknowledgements}

This work was supported by the NIH grant EB-001475 and Department of Energy grant 96ER20237 and by the Office of Vice President for Research at The University of Michigan.

\section{References}

1. Anthony, C. The Biochemistry of Methanotrophs. The Academic Press; london: 1982.

2. Dalton H. Phil Trans Royal Society of London, Series B: Biological Sciences 2005;360:1207-1222.

3. Dalton CPSD, Leak DJ, Stanley SH. Microbial Growth on C1 Compounds 1984:75-82.

4. Prior SD, Dalton H. J Gen Microbiol 1985;131:155-163.

5. Stanley SH, Prior SD, Leak DJ, Dalton H. Biotech Lett 1983;5:487-492.

6. Choi DW, Kunz RC, Boyd ES, Semrau JD, Antholine WE, Han JI, Zahn JA, Boyd JM, de la Mora AM, DiSpirito AA. J Bacteriol 2003;185:5755-5764. [PubMed: 13129946]

7. Murrell JC, McDonald IR, Gilbert B. Trends Microbiol 2000;8:221-225. [PubMed: 10785638]

8. Stolyar S, Franke M, Lidstrom ME. J Bacteriol 2001;183:1810-1812. [PubMed: 11160118]

9. Fox BG, Froland WA, Dege JE, Lipscomb JD. J Biol Chem 1989;264:10023-10033. [PubMed: 2542319]

10. Green J, Dalton H. J Biol Chem 1985;260:15795-15801. [PubMed: 3934164]

11. Wallar BJ, Lipscomb JD. Chem Rev 1996;96:2625-2657. [PubMed: 11848839]

12. Wallar BJ, Lipscomb JD. Biochemistry 2001;40:2220-2233. [PubMed: 11329291]

13. Fox BG, Surerus KK, Münck E, Lipscomb JD. J Biol Chem 1988;263:10553-10556. [PubMed: 2839495]

14. Elango WA, Radhakrishman R, Froland WA, Wallar BJ, Earhart CA, Lipscomb JD, Olhendorf DH. Protein Sci 1996;6:556-568. [PubMed: 9070438]

15. Liu KE, Valentine AM, Wang A, Huynh BH, Edmondson DE, Saligoflou A, Lippard SL. J Am Chem Soc 1995;117:10174-10185.

16. Fox BG, Hendrich MP, Surerus KK, Andersson KK, Froland WA, Lipscomb JD, Münck E. J Am Chem Soc 1993;115:3688-3701.

17. Basu P, Katterle B, Andersson KK, Dalton H. Biochem J 2003;369:417-427. [PubMed: 12379148]

18. Lieberman RL, Shrestha DB, Doan PE, Hoffman BM, Stemmler TL, Rosenzweig AC. PNAS 2003;100:3820-3825. [PubMed: 12634423]

19. Takeguchi M, Miyakawa K, Okura I. J Mol Cat A 1998;132:145-153.

20. Zahn JA, DiSpirito AA. J Bacteriol 1996;178:1018-1029. [PubMed: 8576034]

21. Lieberman RL, Rosenzweig AC. Nature 2005;434:177-182. [PubMed: 15674245]

22. Nguyen HH, Elliott SJ, Yip JH, Chan SI. J Biol Chem 1998;273:7957-7966. [PubMed: 9525893]

23. Hakemian AS, Rosenzweig AC. Ann Rev of Biochem 2007;76:223-241. [PubMed: 17328677]

24. Chan SI, Chen KHC, Yu SSF, Chen CL, Kuo SSJ. Biochemistry 2004;43:4421-4430. [PubMed: 15078087] 
25. Chan SI, Wang VCC, Lai JCH, Yu SSF, Chen PPY, Chen KHC, Chen CL, Chan MK. Angew Chem Int Ed 2007;46:1992-1994.

26. Choi DW, Antholine WE, Do YS, Semrau JD, Kisting CJ, Kunz RC, Campbell D, Rao V, Hartsel SC, DiSpirito AA. Microbiology 2005;151:3417-3426. [PubMed: 16207923]

27. Myronova N, Kitmitto A, Collins RF, Miyaji A, Dalton H. Biochemistry 2006;45:11905-11914. [PubMed: 17002291]

28. Takeguchi M, Ohashi M, Okura I. BioMetals 1999;12:123-129.

29. Tukhvatullin IA, Gvozdev RI, Andersson KK. Biochem Biophys Mol Biol 2000;374:177-182.

30. Lieberman RL, Kondapalli KC, Shrestha DB, Hakemian AS, Smith SM, Telser J, Kuzelka J, Gupta R, Borovik AS, Lippard SJ, Hoffman BM, Rosenzweig AC, Stemmler TL. Inorg Chem 2006;45:8372-8381. [PubMed: 16999437]

31. DeWitt JG, Bentsen JG, Rosenzweig AC, Hedman B, Green J, Pilkington S, Papaefthymiou GC, Dalton H, Hodgson KO, Lippard SJ. J Am Chem Soc 1991;113:9219-9235.

32. Lesuisse E, Santos R, Matzanke BF, Knight SAB, Camadro JM, Dancis A. Hum Mol Gen 2003;12:879-889. [PubMed: 12668611]

33. Vrajmasu VV, Bominaar EL, Meyer J, Münck E. Inorg Chem 2002;41:6358-6371. [PubMed: 12444779]

34. Long, GL. Mossbauer Spectroscopy Applied to Inorganic Chemistry. 2. Plenum Press; New York: 1984.

35. The magnetic spectra of superparamagnetic particles are exceedingly complex as they depend on the size, shape and shape distribution of these particles, see ref. ${ }^{34}$.

36. Semrau JD, Chistoserdov A, Lebron J, Costello A, Davagnino J, Kenna E, Holmes AJ, Finch R, Murrell JC, Lidstrom ME. J Bacteriol 1995;177:3071-1379. [PubMed: 7768803]

37. DiSpirito AAGJ, Schiemke AK, Murrell JC, Lidstrom ME. Biodegradation 1992;2:151-164.

38. Hyman MRADJ. J Biol Chem 1992;267:1534-1545. [PubMed: 1730700]

39. Prior SD, Dalton H. FEMS Microbiol Lett 1985;29:105-109. 


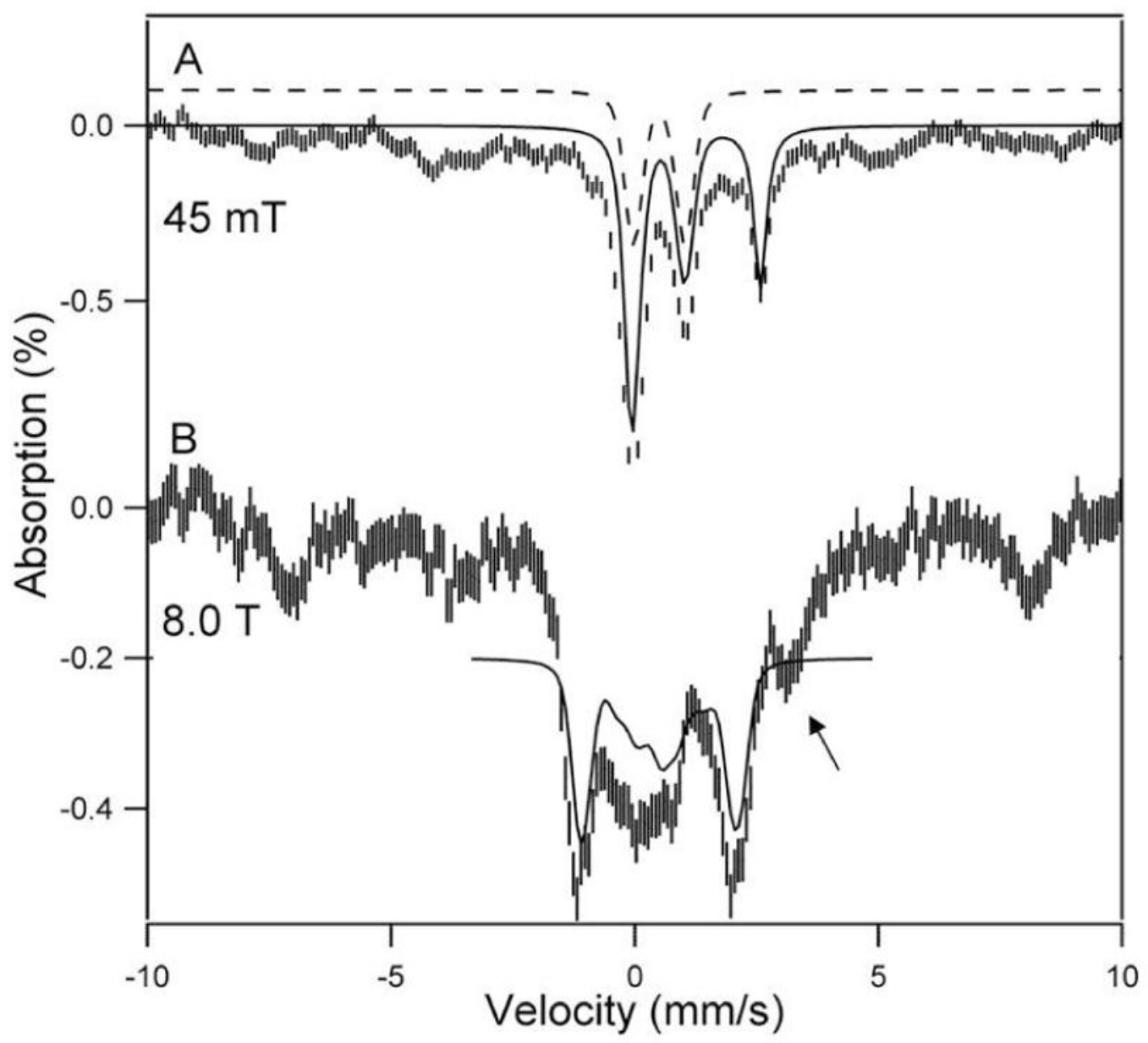

Figure 1.

4.2 K Mössbauer spectra of anaerobically purified pMMO recorded in parallel applied fields of $45 \mathrm{mT}(\mathrm{A})$ and $8.0 \mathrm{~T}(\mathrm{~B})$. The solid line in (A) is a spectral simulation for doublet 1 , assigned to a diamagnetic diiron(III) center $\left(20 \%\right.$ of $\mathrm{Fe}$ ), and a high-spin $\mathrm{Fe}^{2+}(18 \%)$ component. The remainder of the absorption (magnetic components) belongs to various high-spin $\mathrm{Fe}^{3+}$ species. The dashed line outlines doublet 1 . The solid line in (B) is a spectral simulation for the putative diiron(III) center, assuming $\mathrm{S}=0$ and equivalent sites with $\triangle \mathrm{EQ}=+1.05 \mathrm{~mm} / \mathrm{s}, \eta=0.8$ and $\delta$ $=0.50 \mathrm{~mm} / \mathrm{s} ; \eta$ is the asymmetry parameter of the electric field gradient tensor. The arrow points at the high energy feature of the high-spin ferrous component. A second sample, exposed to oxygen after purification, gave identical spectra. 


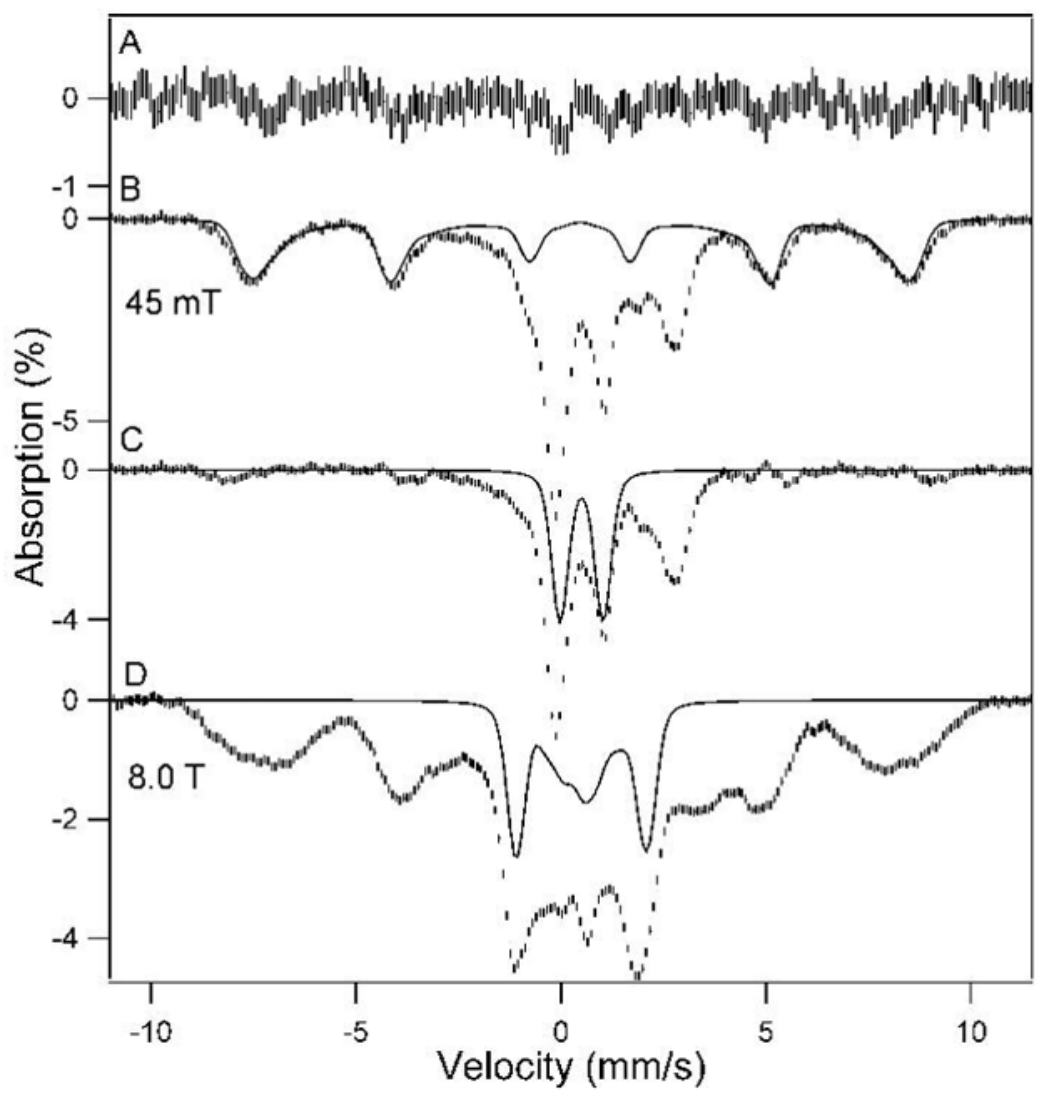

Figure 2.

4.2 K Mössbauer spectra of $M$. capsulatus Bath cells grown at $5 \mu \mathrm{M} \mathrm{Cu}$ and $5 \mu \mathrm{M}^{57} \mathrm{Fe}(\mathrm{A})$ and at $80 \mu \mathrm{M} \mathrm{Cu}$ and $40 \mu \mathrm{M}^{57} \mathrm{Fe}(\mathrm{B}-\mathrm{D})$. The spectra were recorded in parallel applied fields as indicated. The sample of (B) and (D) consisted of cells grown at $80 \mu \mathrm{M} \mathrm{Cu}$ and 40 $\mu \mathrm{M}{ }^{57} \mathrm{Fe}$, then harvested, washed, and resuspended anaerobically. The solid line in (B), representing $40 \%$ of the ${ }^{57} \mathrm{Fe}$, is a simulation of the superparamagnetic component, obtained by superimposing four high-spin ferric spectra; the simulation was solely aimed at representing the spectral area of this species at one particular applied field. (C) Difference spectrum obtained by subtracting the simulated spectrum of (B) from the raw data of (B). The solid line represents doublet $1\left(20 \%\right.$ of $\left.{ }^{57} \mathrm{Fe}\right)$. (D) $8.0 \mathrm{~T}$ spectrum. The solid line is a simulation assuming that the iron of doublet 1 is diamagnetic. 

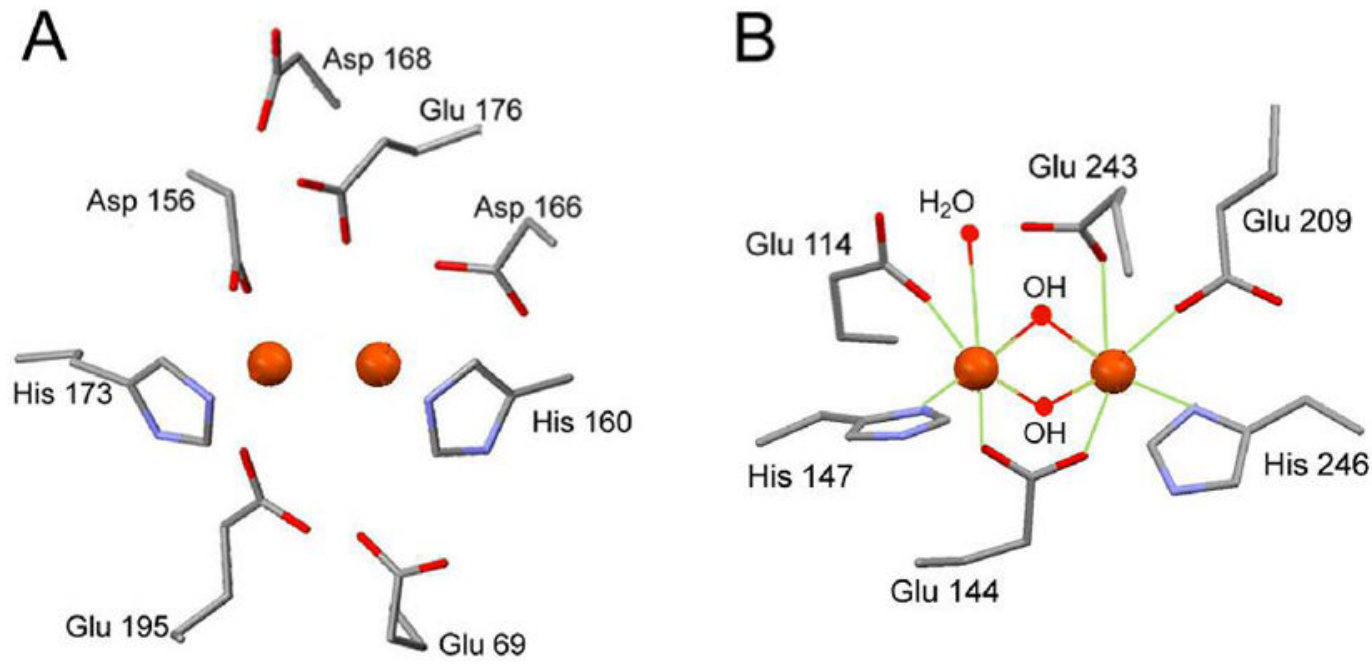

Figure 3.

(A) Replacement of the mononuclear $\mathrm{Zn}$ by a diiron center in the X-ray structure of pMMO. 21 (B) Environment of the diiron center in the sMMO from M. trichosporium OB3b. ${ }^{14}$ 
Table 1

Properties of whole cells and purified pMMO Mössbauer samples.

\begin{tabular}{lcc}
\hline & Whole Cells & PMMO \\
\hline$\alpha \beta \gamma(\mathrm{mM})$ & 0.56 & 1.06 \\
Total Fe $(\mathrm{mM})$ & 5.2 & 1.2 \\
Fe in doublet $1(\mathrm{mM})$ & 1.04 & 0.24 \\
Diiron $(\mathrm{III}) / \alpha \beta \gamma$ & 0.93 & 0.11 \\
Activity $\left(\mathrm{nmol} \cdot \mathrm{min}^{-1} \cdot \mathrm{mg} \mathrm{pMMO} \mathrm{protein}{ }^{-1}\right)$ & $\sim 1500$ & 160 \\
\hline
\end{tabular}

